\title{
The Zalew Balaton Quarry geosite in Trzebinia, southern Poland: an update of geological data
}

\author{
Sylwester Kamieniarz \\ University of Silesia, Faculty of Earth Sciences, Student's Geological Scientific Association, \\ ul. Będzińska 60, 41-200 Sosnowiec; \\ e-mail: sylwek.k0@op.pl
}

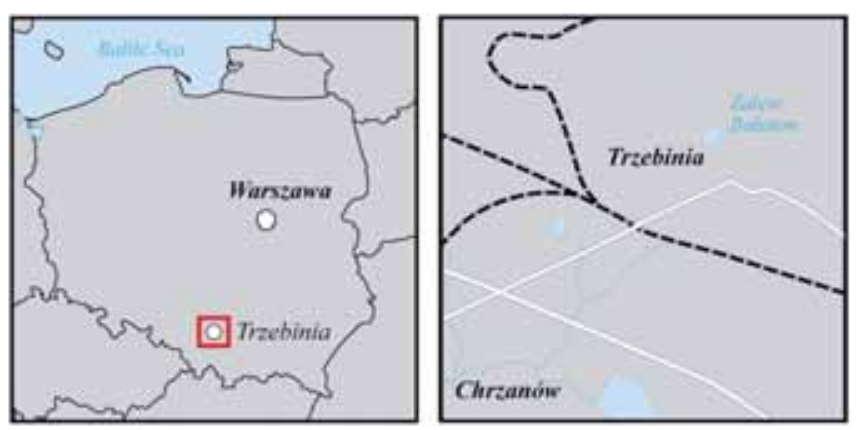

Abstract: A development project of the Zalew Balaton area is being presently carried out. One of the project assumptions is to create a geological path across the object. However, detailed data about the geological structure of this place is not available. For this reason, the author has researched and updated the information about the rocks occurring in the walls of the old quarry. Primarily, terrain (textural and structural analysis, layers strike and dip measurements, geological boundaries delimitation) and laboratory analysis (X-Ray Powder Diffraction, microscopic rock samples analysis) were conducted. Collected data was afterwards compared with available literature.

Within the steep slopes of excavation, strong-karsted, faulted Upper Jurassic (Oxfordian) carbonate sediments were revealed. These are massive, platy and crumpled limestone. These rocks could be deposited in changing conditions of sedimentation, when calm carbonate sedimentation was disturbed by underwater gravity flows, as demonstrated by their detrital character. One of the karst funnel on the northern slope was filled with Oligocene sand. As a result, groundwater fluctuations created a sarsen structure, popularly called the "Wielbład". In relation to the planned geological path across the Zalew Balaton area, previous knowledge should be supplemented with new data, respectively processed and included on information panes, located within object. Plans of the path should pay attention to potential geotouristic safety, as well as to the geological values of the protected object, during its future modernization. Key words: closed quarry, Upper Jurassic, limestone, "Wielbład", sarsen

\section{Introduction}

Since 2013, a development project of the Zalew Balaton area in Trzebinia is being implemented. According to the concept, a city park will be created in this place, to provide recreational, sport and educational functions. To educate, a geological path will be formed. (Adamczak et al., 2012; Pietrzyk-Sokulska, Kulczycka, 2013). Its task will be to present visitors with the geological structure of this place.

Recreational and nature singularities of the Zalew Balaton were described well in many local tourist guidebooks and booklets (e.g. http://www.trzebinia.pl/_files_/zielone_perly. pdf). On the other hand, synthesized and detailed data about the geological structure are little available. One of the first published papers mentions the rocks occurring in the Zalew Balaton area in Professor's Dżułyński work (Dżułyński, 1952). In this paper, geological-stratigraphic data of the Zalew Balaton was marked on the Detailed Geological Map of Poland 1:50000, Chrzanów sheet (Żero, 1956). In later times, this region was included in the publications related to the Krzeszowice trench and its edge themes (Bogacz, 1967; Felisiak, 1992). In the first decade of the twenty-first century, a team from the AGH University of Science and Technology in Kraków became interested in the geological curiosities of Trzebinia. As a result, the geological-didactic trial across the community was created. (Głogowska, Paulo 2003). The Zalew Balaton also was the subject of a study of a doctoral dissertation, which actually contains the best, published geological description of the Zalew Balaton area (Głogowska, 2007). Finally, the object figures in the Polish Central Register of Geosites (http://geoportal.pgi.gov.pl/portal/page/portal/geostanowiska).

However, the above-mentioned elaborations do not describe in detail the rocks occurring in the Zalew Balaton area. What is more important, is that there are no geological sketches or cross-sections, which could show spatial distribution types of the rocks. In addition, a genetic interpretation of these sediments is unknown. Moreover, the interpretation of the biggest geological curiosity of this place seems to be incorrect. For these reasons, and to fulfill the educational function of the Zalew Balaton,, the author decided to look closer at the rocks occurring in this place and synthesize, correct and enlarge the existing knowledge.

Terrain and laboratory studies were conducted. In the first research group, a textural and structural analysis of the rocks was conducted. Layers strike and dip were measured. This data was used to provide a geological boundary designation, followed by a geological sketch with cross-section analysis. Three rock samples were collected and used for laboratory research, such as X-Ray Powder Diffraction and a petrographic microscopic analysis. Detailed description of the research is in the following publication chapters. Investigation results were compared with available literature and presented in this paper.

\section{Location and short history of the area}

The Zalew Balaton is located in Trzebinia city, within the Małopolska voivodeship and Chrzanów district, near the crossroads of the national road No. 79 and the provincial road No. 791, at St. Stanisław Street (Fig. 1). 


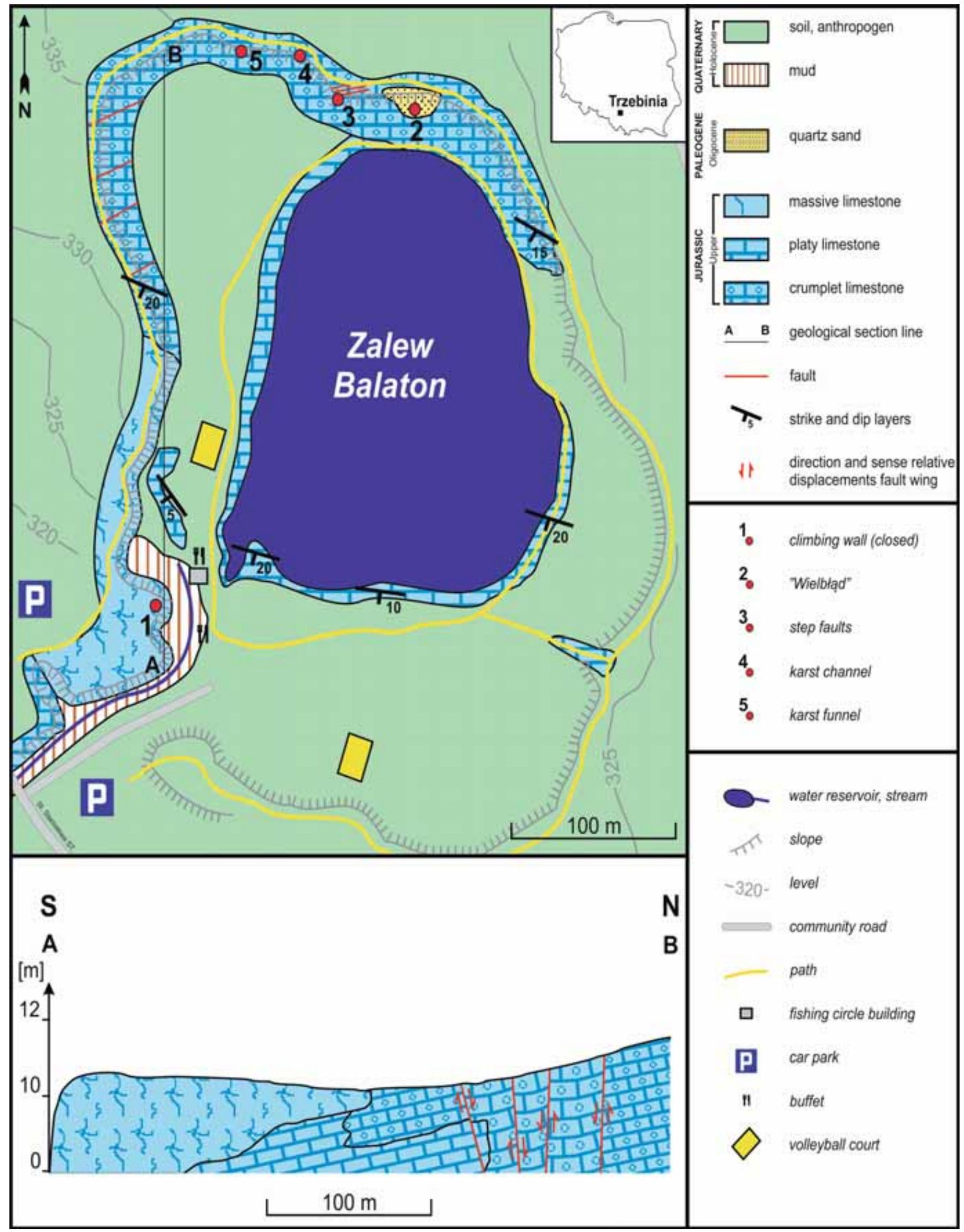

Fig. 1. Geological-situational sketch of the Zalew Balaton area, with a simplified cross-section, along the western wall of the old quarry

Tectonically, this area belongs to the Silesian-Cracow place (Głogowska, 2007). It belonged to the horst-nature, isomonocline. Formerly, the elevation with a height of $346 \mathrm{~m}$ lated hills band of the Silesian Upland, called Garb Ciężkowabove sea level, called the Godyniowa Skała existed in this icki, located within the Wilkoszyńska trough (Bogacz, 1967; 
Gilewska, 1972). In 1913, the "Górka" company began to mine there, thereby transforming this elevation into a limestone quarry. Mined soil was transported to a nearly processing plant, where it was used for cement production. At the end of the 60's, parts of the quarry were accidentally flooded. This led to the closure of production in 1974, due to the high costs of resuming exploitation (Domańska, 1995). Two lowest mining levels were totally flooded, and the object quickly became a picturesque recreational place for Trzebinia and surrounding residents (Fig. 2). The newly-created water reservoir was called Zalew Balaton.

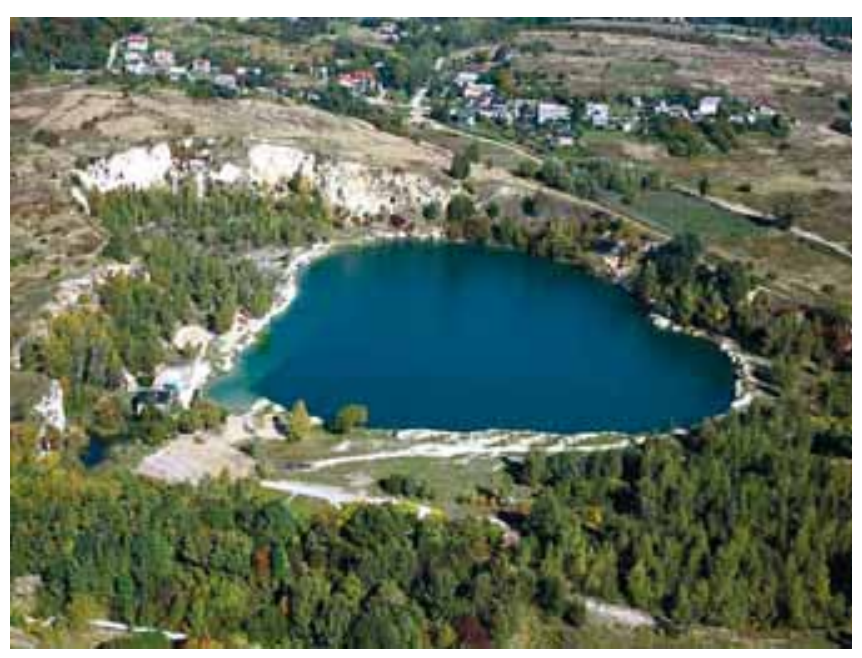

Fig. 2. Bird's eye view of the Zalew Balaton area towards the north (source: http://gminyturystyczne.pl/pokaz/trzebinia)

\section{The geological structure of the Zalew Balaton area}

The highest, earliest formed and not inundated mining level extends into the closed quarry which has area of 10,60 ha. The walls of the excavation are steep or very steep, and in some places vertical. Their height varies from 10 to $25 \mathrm{~m}$. Taluses commonly occur at the base of the slopes. Locally, especially in the northern part of the quarry, the height of the taluses reaches more than half of the slopes. The quarry area is largely covered by grass, shrubs and trees. This makes geological observation more difficult.

Within the closed quarry, the Upper Jurassic, Upper Oxfordian limestone is exposed (Żero, 1956; Głogowska, 2007; Fig. 1). These rocks can be observed on the slopes of the excavation, mainly in the western, north-western, and northern parts and along the edges of the reservoir. In the other parts of the area, these sediments are under a weathering cover or they are covered by soil and plants. The limestone accordingly is located on the older Middle Oxfordian marl, which does not crop out (Żero, 1956). Distinct variation in the structure of carbonates can be noticed along the western wall, extending from the main entrance of the quarry. Three types of limestone can be distinguished, according to their textural and structural differences (Fig. 1).
The first type is clearly visible in the western part, near the main entrance of the quarry (Fig. 1). From a distance, it resembles the massive, microbial-sponge rocky limestone, of light gray color (Dżułyński, 1952; Głogowska, 2007). On the whole, it is not layered, but locally tends to be made up of very indistinct thick-bedding and is very cracked. The limestone shows a variable detrital structure (Fig. 3). The intraclasts are composed of carbonate mud, and the bioclasts are represented by calcified skeletons of sponges. Textural parameters of the intraclasts are quite varied. One can notice their spherical and irregular forms. Their diameter varies from a few to several centimeters, extending up to $50 \mathrm{~cm}$. The intraclasts usually are angular. The bioclasts diameter does not exceed few centimeters. All these clasts are dispersed in a micrite mass. The cement is more prone to the erosion process. As a result, the intraclasts and bioclasts are clearly exposed on the wall. Inside the rock, the arrangement of the components is chaotic. The rock is broken unevenly or in a spikey manner. Summarizing, it can be suggested, that these rocks are not typical massive limestone, but, rather, a type similar to it. Most likely, the same deposits occur in the south-western wall of the quarry (based on the upper part of the slope observation), but considerable coverage of the area with the soil and vegetation cannot confirm this assumption.

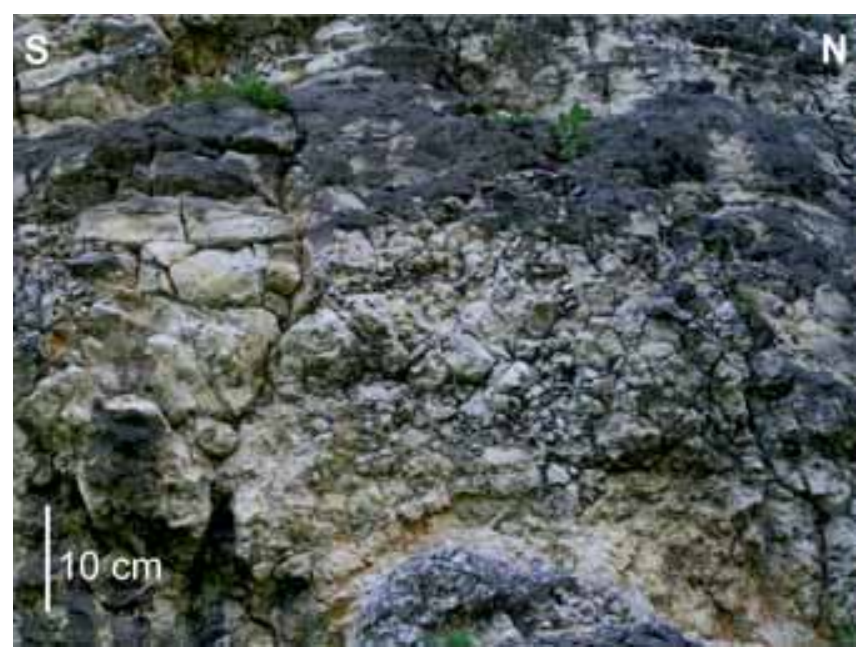

Fig. 3. Detrital character of the massive limestone, western wall, photo S. Kamieniarz

Further to the north, along the western wall of the quarry, a layering, whitish or pale creamy platy limestone exposes gradually from the erosional, lower limit of the massive limestone (Fig. 4). This limestone is also exposed in the mechanically created hill near the Fishing Association building and in the north-western, western, southern and south-eastern edges of the reservoir (Figs 1, 5). Therefore, it can be concluded, that this type of limestone forms the basis of the entire basement of the oldest mining level and probably of the south-eastern wall of the quarry as well.

The thickness of the beds varies from $15 \mathrm{~cm}$ to more than $60 \mathrm{~cm}$, remaining generally constant. Bed surfaces, generally smooth, tend to be locally disrupted (usually on contact with 
other types of limestone). In such cases, their thickness is variable within the beds. Layers dip gently (up to $20^{\circ}$ ) towards the south-west. In the texture of this limestone, calcilutite limestones dominate, but near the meeting point with other types of limestone, the share of calcarenite and calcirudite increases. The rock is broken breaks unevenly or in a spikey manner. Fossils of brachiopods, sponges and ammonites are common within this limestone. Rust raids occur in some places on layer surfaces, as a result of pyrite oxidation (Głogowska, 2007).

Moving further towards the western wall of the quarry, platy limestone laterally passes through into yellowish limestone, with a crumpled structure (Fig. 1). It is worth noting, that the lateral transition from platy to crumpled limestone is irregular.

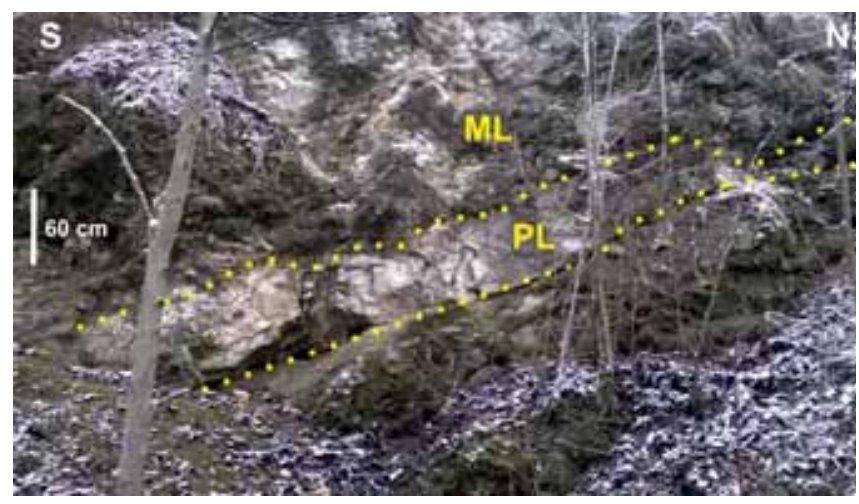

Fig. 4. A contact zone between massive and platy limestones, western wall: ML - massive limestone; PL - platy limestone; a yellow dotted line presents bed surfaces of the platy limestone. Tops of the platy limestones are disturbed; photo S. Kamieniarz
Both of these types of limestone often overlap each other. As such, the boundaries proposed in the geological sketch are slightly simplified. Within these rocks, layering occurs, although blurred in some places. The thickness is generally constant within the beds and ranges from $20 \mathrm{~cm}$ to $60 \mathrm{~cm}$. The bed surfaces are uneven. Layers dip towards the south-west, at an angle of $15-20^{\circ}$. This type of limestone exhibits various frequently occurring shapes and sizes, as well as angular or sub-angular lumps, made up of concise, gray carbonate mud (Fig. 6). In these lumps, fragments of sponge skeletons, reaching up to several centimeters, can often be observed. The clasts are chaotically deployed in a yellowish substance, containing a small admixture of clay. Less concise, calcarenite matrix, together with sponge (predominantly), ammonite, belemnite and sea urchin fossils can also be seen. The rock is broken unevenly. This type of limestone is very susceptible to weathering processes. As a result, at the foot of the walls, considerably sized taluses tend to form. Within these sediments, in the western and north-western wall of the quarry, a dislocation zone can be observed, consisting of a series of steep dip angles of $75-85^{\circ}$, normal dip-slip faults, striking southwest-northeast, together with accompanying fractures (Fig. 1). The amplitude of the throw, along the single fault surface, ranges from few to $25 \mathrm{~cm}$. The genesis of this zone may be related to Oligocene-Miocene tectonic movements, which led to the formation of the Krzeszowice trench (Felisiak, 1992). They are best visible from the quarry crown, where the characteristic fault drags of the layers can be observed. The crumpled limestone also continues along the northern and north-eastern slopes of the excavation, where it has a more massive structure. In these parts, steeply inclined, normal dip-slip faults can be observed on the northern slope of the quarry (Figs 1, 7).

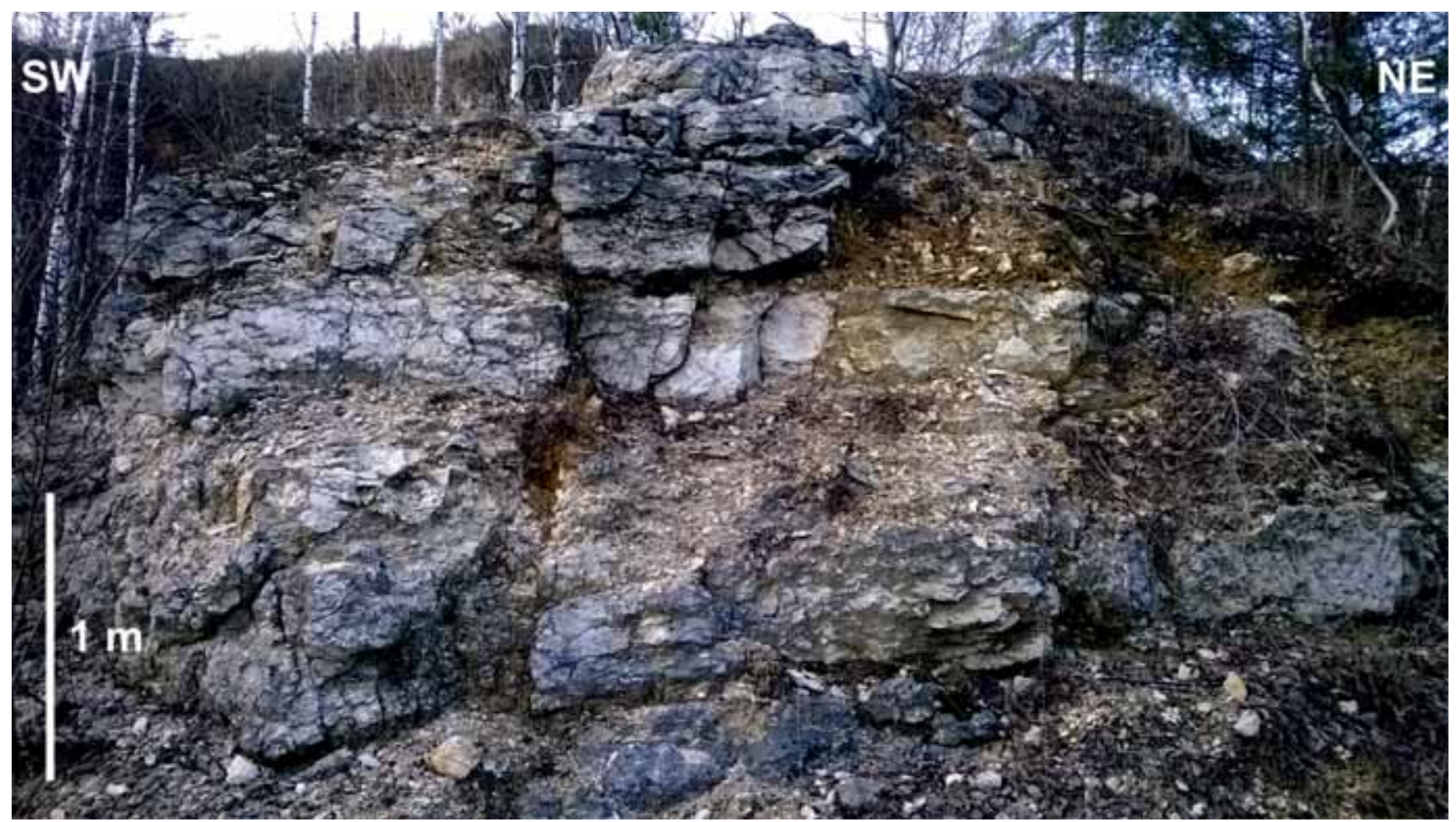

Fig. 5. Mechanically created outcrop of the platy limestone near the Fishing Association building, photo S. Kamieniarz 


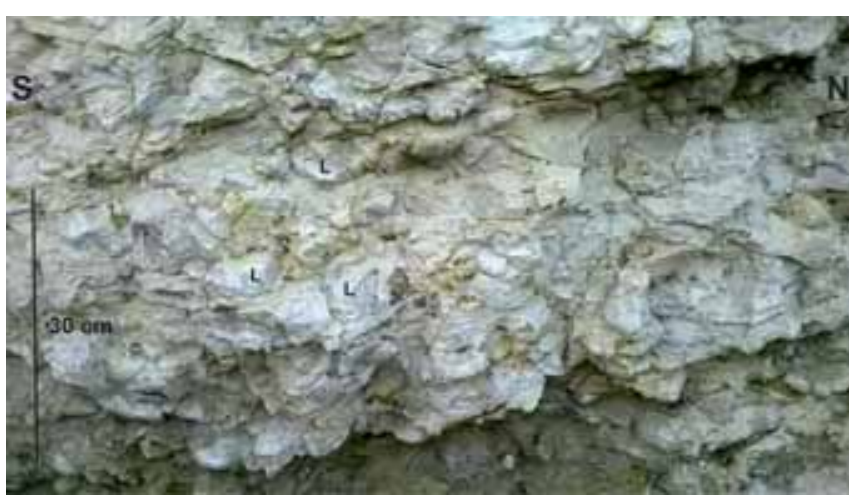

Fig. 6. Crumpled limestone bed in the western wall of the quarry: L - lumps; photo S. Kamieniarz

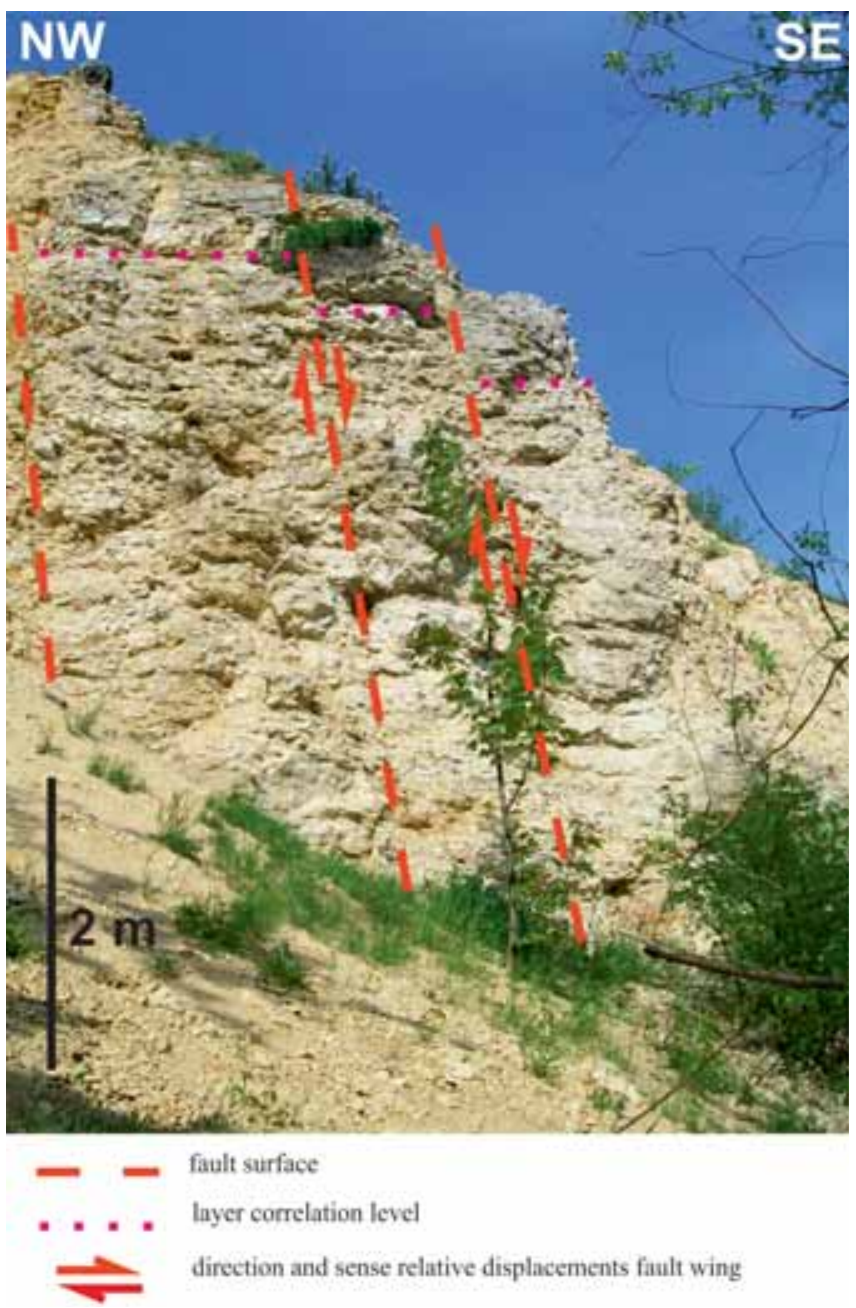

Fig. 7. Steep (consequent, homothetic) dip-slip faults in the northern slope of the excavation, photo S. Kamieniarz

Fault surfaces dip toward the SSE at an angle of $80^{\circ}$, whereas the throw is about $6 \mathrm{~m}$ high (Głogowska, 2007). Most likely, these surfaces are the result of exploitation and stress, which has led to changes, weakening the stability of the slopes and causing gravitational rocks displacement along the surface of the discontinuity.

The Upper Jurassic carbonates from the Zalew Balaton are strongly karsted. Structures such as karst funnels, slots and channels can be observed on the quarry walls (Figs 1,8).
Most of the karst paleoforms, due to the exploitation and instability mentioned above, were unveiled as filler material slid down the slopes (Figs 1,9). Only on the northern slope, white and gray Oligocene quartz sand has preserved in some fossil karst structures. These quarts originated from Cretaceous sediments, which were eroded at the end of the Paleogene (Felisiak, 1992).

The Holocene fluvial sediment, mainly mud, is the youngest deposit occurring in the Zalew Balaton area. It is well exposed in the stream valley in the south-western part of the closed quarry (Fig. 1).

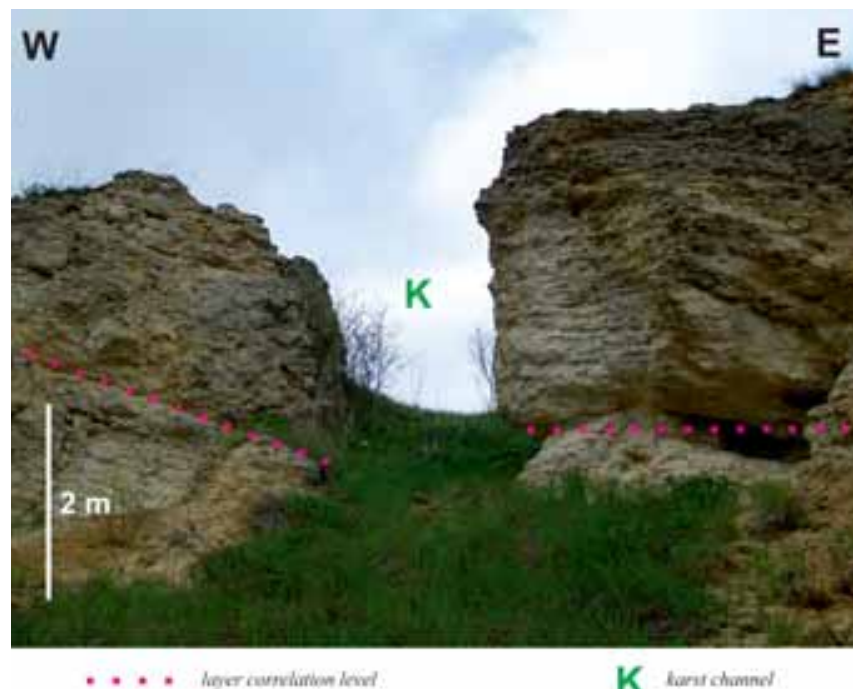

Fig. 8. Karst channel in marly crumpled limestone, northern wall, photo S. Kamieniarz

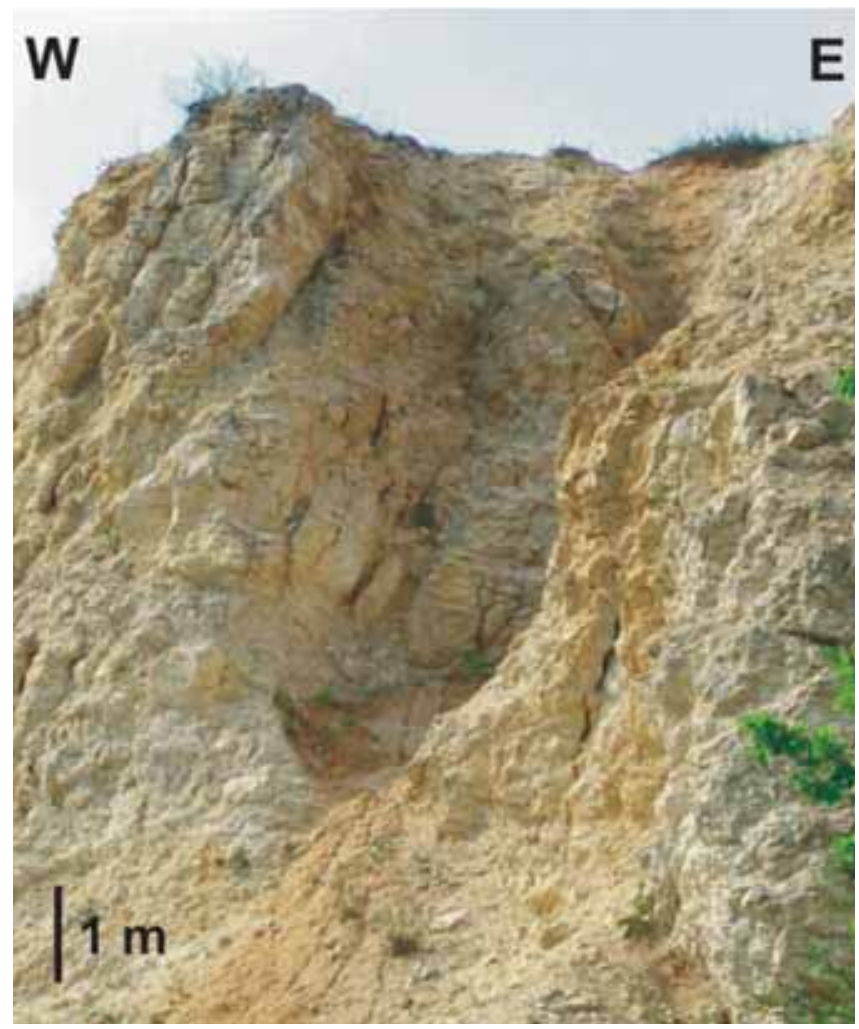

Fig. 9. Erosion-dissected karst funnel in the northern quarry wall, phot. S. Kamieniarz 


\section{Upper Jurassic limestone in the Zalew Balaton area - genesis}

Taking into account all the textural and structural features of the limestone occurring in the Zalew Balaton area, it can be suggested that it is connected with underwater mass flows of high density (debris flow). This conclusions stems from observation of the following features (Radomski, 1986; Vierek, 1997):

- bimodality grain composition and dispersion of the clasts the massive, crumpled and locally platy limestone has a matrix, which is composed of smaller fractions. In this mass, bigger clasts are chaotically dispersed;

- dominance of massive structures - rocky limestone has a massive structure and its indistinct thick-bedding can be interpreted as a flow surfaces. Within the crumpled limestone, massive structure can also be found;

- erosional lower limits of sediments - the base of the massive limestone shows erosion;

- perturbation of underlain sediments - near the contact zone, between the massive and platy limestone, the top surface of the platy limestone shows disturbance.

About 150-160 million years ago, a shallow, epicontinental sea was in this area. Within its shelf, below the wave base, calm carbonate sedimentation took place, and life flourished. A microbial-sponge along with massive mud mounds were created, around which layered sediments were deposited. Although oxidizing conditions prevailed in general, locally reducing conditions, associated with the backfilling by calcareous mud organic matter, were noticed (Dżułyński, 1952). Rust spots occur on the surface of the platy limestone. During the Late Oxfordian, as tectonic tension increased, the calm sedimentation was disturbed by catastrophic episodes, manifested in numerous underwater mass movements. Their result is the detrital character of the limestone (Vierek et al., 2011). The platy limestone is detrital only in the points of contact with other types of limestone. Therefore, it can be suggested, that the massive and crumpled limestone overlapped the platy limestone during the flow. The dominance of an angular roundness of the carbonate detritus is evidence that there must have been a short path for its transportation. The actuating mechanism for the sediment movements is unknown. In Poland, similar deposits also can be found in the Młynka quarry (Hoffman, Matyszkiewicz, 1989), Ujazd (Matyszkiewicz, 1989) and Bydlin (Vierek, 1997).

\section{The "Wielbłąd" ("Camel") structure}

In the central part one of the fossils, through the sandfilled karst funnel in the northern slope (Fig. 1), a cylindrical block of sandstone occurs. It has about one and half meters in diameter. This structure is called the "Wielbłąd" (eng. "Camel"), because (Głogowska, 2007), it resembled this animal, before 2001 when its mount slid to the reservoir. Wielbłą is the main geological curiosity of this place. Macroscopically, the construction of the "Wielbłąd" can be divided into two parts: the inner, more concise part in light gray; and the external, less concise part where the color gradually changes to cocoa towards the edge (Fig. 10). The "Wielbłąd" surface is covered by well-rounded, small (several centimeters) holes of different shapes and inscriptions carved by humans. Kubajak (2000) and Głogowska (2007), called this structure the quartzite concretion, which was formed from fine sand, coming from siliceous sponge spicules that were less crystallized and consequently more dissoluble. Thus it could create larger units. This view is questionable, because the structure does not resemble a concretion macroscopically. To test this theory, three rock samples were collected: sand from the karst funnel, where the object is located; and external and internal fragments of the "Wielbłąd". The X-Ray Powder Diffraction analysis revealed that samples from the inner and outer parts of "Wielbłąd" are represented only by low-temperature quartz. The analysis of the funnel-filling sand has also revealed the dominance of $\alpha$ quartz, with a small (4-6 wt\%) amount of kaolinite. These results exclude the possibility that the structure was created from the silica sponge. In such a case quartz polymorphs, such as cristobalite and tridymite, would have been present in the analysis.

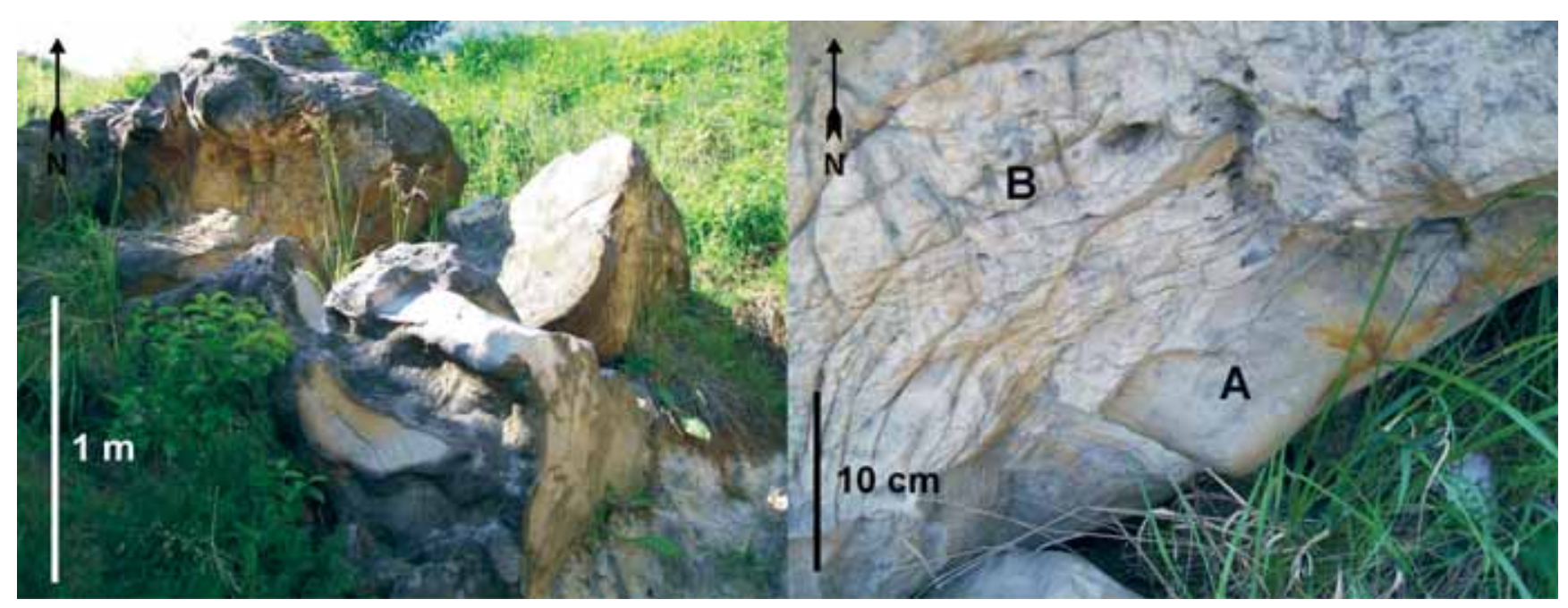

Fig. 10. Parts of the „Wielbłąd” (on the left) and its structure (on the right): A - internal part, more consolidated; B - external part, less consolidated, photo S. Kamieniarz 


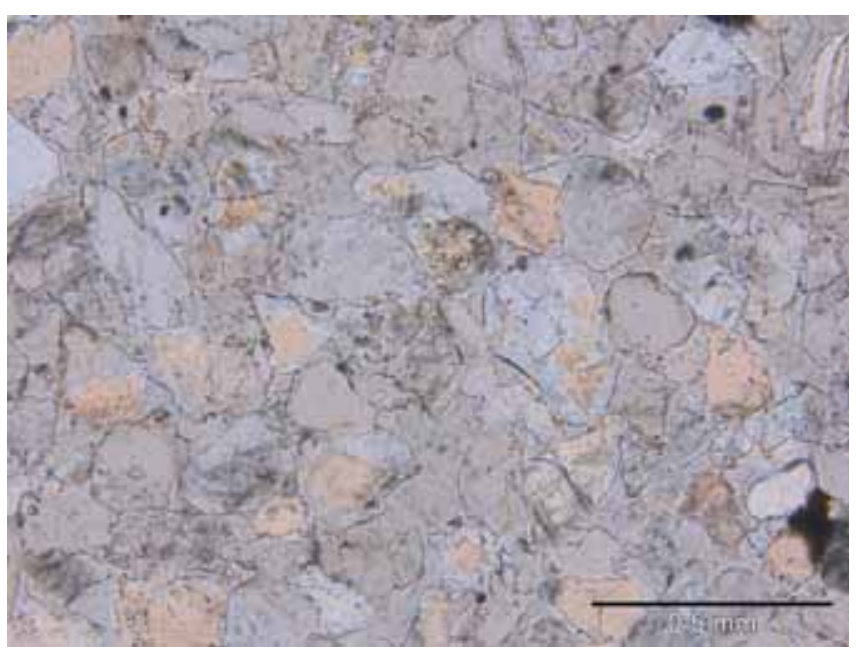

Fig. 11. Microscopic view of the internal part of the "Wielbłąd"

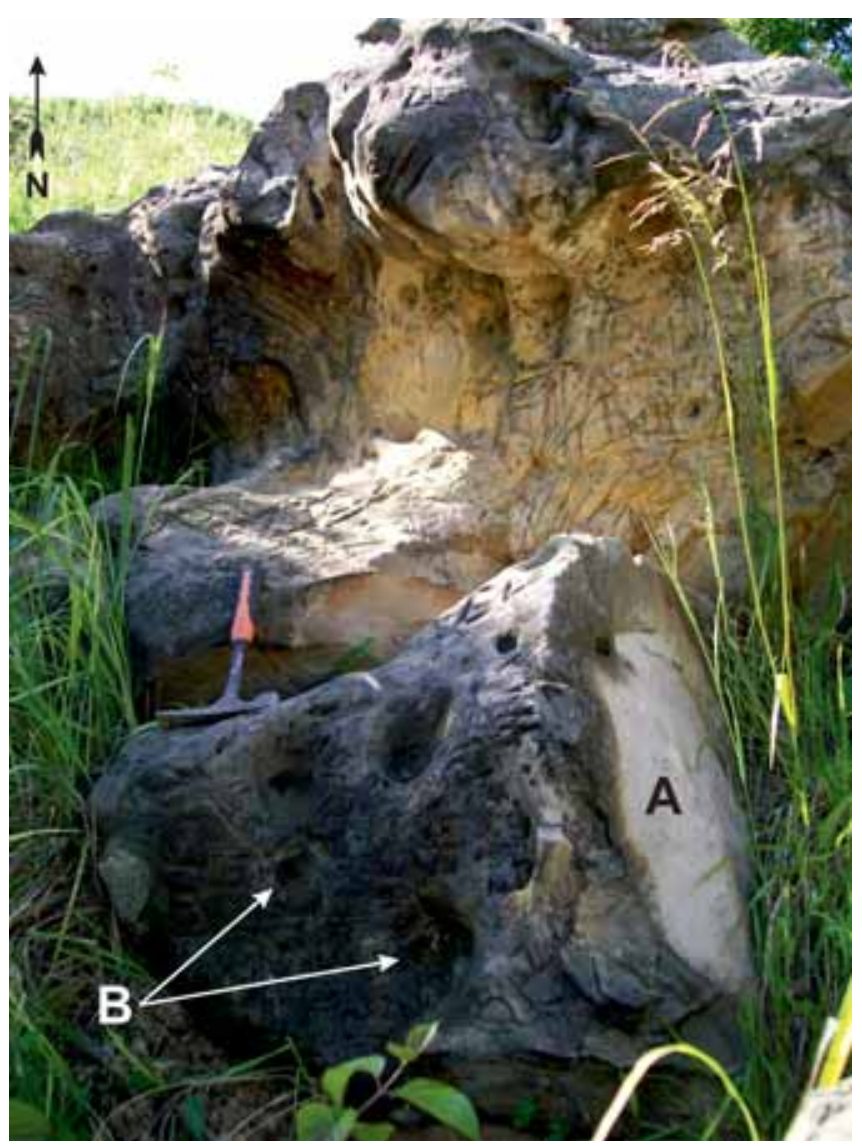

Fig. 12. "A sleeping camel" - in the foreground can be seen a "head" (A), where the root holes (B) resemble the "eyes" and a "nose". In the background is part of the "hump", photo S. Kamieniarz

In the microscopic view of the internal part of the "Wielbłąd", silica is observed in various forms, ranging from automorphic grains to xenomorphic cement, filling the intergranular space (Fig. 11). The grain sections have diameters ranging from $0,025 \mathrm{~mm}$ (minimum) to $0,25 \mathrm{~mm}$ (maximum); $0,15 \mathrm{~mm}$ on average. The quartz clasts are mainly high spherical, sub-angular or sub-rounded. The relief between the edges of the components and the background is high. Related grain boundary dominates. A mainly linear and concave-convex contact between boundaries can be observed. However, at local point, dovetail contact and free grains also occur. Within the entire sample, fragments of sponge spicules and other fauna were not found. This is a further evidence for the nonsponge origin of the "Wielbłąd".

In conclusion, it can be suggested, that "Wielbłąd" was not created from siliceous sponges and is not a quartzite concretion. So what can it be? Its textural and structural features are very similar to sarsen (silcrete) - the Cenozoic sandstone, a product of subsurface silicification, for which sandy sediment was the source material (Summerfield, 1979; Dudun, 2012). A very high silica content, exceeding $97 \%$, is a characteristic feature of these structures (Ullyott et al., 2004). Genetically, two types of silcrete are distinguished; pedogenic and groundwater silcretes (Nash, Ullyott, 2007). The first pedogenic ones form during weathering, with subsurface layers undergoing soil processes. Eventually they create extensive rock covers on their surface. The groundwater silcretes are associated with groundwater level fluctuations and occur as single or superimposed lenses within non-cemented sediments. The location of the "Wielbłąd" inside the sand-filled karst funnel and its shape suggest a genesis associated with a variable hydrological regime. The holes, mentioned at the beginning of this chapter, may be typical for sarsens something missing the root holes (Fig. 12). Their origin is associated with the presence of unconsolidated sediment plant roots, indicating a subsurface environment when the structure was formed (Summerfield, 1979).

\section{Summary and conclusions}

Upper Jurassic carbonate sediments, represented by the Upper Oxfordian massive, platy and crumpled limestone, occur in the Zalew Balaton area. Textural and structural analysis has demonstrated that these deposits could be formed under varying conditions; for example, under calm deposition intermittent with underwater gravitational flows of high density. This is manifested by their detrital character. In each type of limestone, an interesting collection of Late Jurassic fossils can be collected (Fig. 13). Numerous karst forms occur in the walls of the old quarry. Most of them are dissected. Some are filled with Oligocene fine-grained sand. The greatest geological attraction of this place is a cylindrical block of quartz sandstone, which is called the "Wielbłąd". It is located on the northern slope, within one of the fossil karst funnels. According to laboratory research coupled with its structural features, this formation seems to be made up of groundwater sarsen. Brittle tectonic structures, such as fault zones, with accompanying fractures, can also be observed within the quarry. They are the result of tectonic movements and/or human activity.

Taking into consideration the geological and other values of this place (e.g. recreational, sport, and so on), the Zalew Balaton area displays good geotouristic potential. This potential will increase when the current development project is finished. At this point, the Zalew area will be transformed into a great city park with a geological path. However, it is important to make sure the geological information is well presented. The author suggests that separate panels and boards, 
containing geological sketches (with interesting geological curiosities), should be created. In addition, cross-sections and descriptions of the rocks occurring in the Zalew Balaton area could support other kinds of facts made available to the public for display. Information included on these plates should be respectively understandable for tourists, and, simultaneously, should encourage geologists to find new and more insightful observations. The panels should be localized at the entrances of the object and around the reservoir. It is important to correctly protect the walls of the reservoir. This suggests that safety of geotourist activity should be the primary objective. Planners will have to elaborate adequate safeguards, which will protect the slopes against falls of the rocks. The second objective is to protect the geotouristic values, especially of the "Wielbłąd" object. This structure is being exposed to landslide processes. The author also suggests that some taluses should be removed to improve geological observation.

At the end of this article, it must be emphasized, that information contained in this paper does not fully exhaust the geological issues of the Zalew Balaton area. Information collected by the author is mainly based on geological observation and measurements, conducted only within the oldest level of the closed quarry. For better understanding of the geological structure of the Zalew Balaton, it is necessary to conduct further research and look more widely (i.e. correlation with other Oxfordian limestone outcrops in the Kraków area). Other deeper research could include that into flooded parts of the closed quarry). However, from a geotouristic perspective, the data contained in this paper is sufficient.

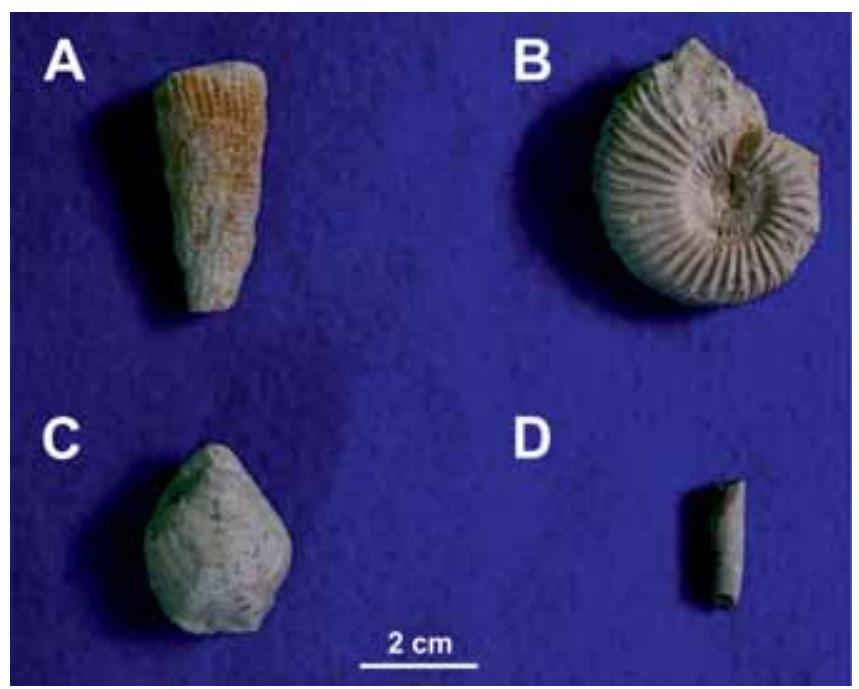

Fig. 13. Late Jurassic fossils collected in the Zalew Balaton area: A - sponge; $\mathrm{B}$ - ammonite; $\mathrm{C}$ - brachiopod; D - fragment of urchin spike, photo S. Kamieniarz

\section{Acknowledgments}

Finally, the author thanks Phd. Krzysztof Gaidzik, MSc. Waldemar Bardziński, Professor Jerzy Żaba for taking the time and helping to elaborate the paper; as well as Phd. Tomasz Krzykawski for the X-ray Powder Diffraction realization and result analysis.

\section{References}

Adamczak F., Danielak B., Duda A., Bednarski M., 2012. Wstępny projekt parku miejskiego. Koncepcja parku miejskiego w Trzebini, obejmujaca tereny Balatonu i Rybnej, część B. SAO Investment, Kraków.

Bogacz K., 1967. Budowa geologiczna północnego obrzeża rowu krzeszowickiego. Prace Instytutu Geologicznego, 41: 7-17.

Domańska J., 1995. Historia Zakładu Surowców Ogniotrwatych „Górka” S.A. w Trzebini. Archiwum MBP, Trzebinia.

Dudun A., 2012. O kręgach kamiennych Stonehenge i Avebury. Przegląd Geologiczny, 60 (5): 257-262

Dżułyński S., 1952. Powstanie wapieni skalistych Jury Krakowskiej. Rocznik Polskiego Towarzystwa Geologicznego, 21: 125-180.

Felisiak J., 1992. Osady krasowe oligocenu i wczesnego miocenu oraz ich znaczenie dla poznania rozwoju i tektoniki okolic Krakowa. Annales Societatis Geologorum Poloniae, 62 (2): 173-207.

Gilewska S., 1972. Wyżyny Śląsko-Małopolskie. In: Klimaszewski M. (ed.), Geomorfologia Polski. Wydawnictwo Naukowe PWN, Warszawa: 232-339.

Głogowska M., 2007. Walory edukacyjne odsłonięć geologicznych i obiektów górniczych $w$ Trzebini. Rozprawa doktorska. Akademia Górniczo-Hutnicza im. Stanisława Staszica w Krakowie, Wydział Geologii, Geofizyki i Ochrony Środowiska, Zakład Analiz Środowiskowych i Kartografii, Kraków: 64-80, http://winntbg.bg.agh.edu.pl/rozprawy/9942/ ful19942.pdf [access: 21.03.2014].

Głogowska M., Paulo A., 2003. Geologiczna ścieżka dydaktyczna: Zalew Balaton. Urząd Miasta w Trzebini.

Hoffman M., Matyszkiewicz J., 1989. Przewodnik 60. Zjazdu Polskiego Towarzystwa Geologicznego. Kraków: 78-83.

Kubajak A., 2000. Osobliwości przyrody Trzebini. Wydawnictwo Kubajak, Krzeszowice.
Matyszkiewicz J., 1989. Przewodnik 60. Zjazdu Polskiego Towarzystwa Geologicznego. Kraków: 83-88.

Nash D.J., Ullyott J.S., 2007. Silcretes. In: Nash D.J., McLaren S.J. (eds), Geochemical Sediments and Land-scapes. Blackwell Publishing, Oxford: 95-143.

Pietrzyk-Sokulska E., Kulczycka J. (eds), 2013. Master Plan dla zbiorników Górka i Balaton. Wydawnictwo IGSMiE PAN, Kraków: 80-90.

Radomski A., 1986. Osady spływów grawitacyjnych. In: Gradziński R. (ed), Zarys sedymentologii. Wydawnictwa Geologiczne, Warszawa: 211-230.

Summerfield M.A., 1979. Origin and palaeoenvironmental interpretation of sarsens. Nature, 281: 137-139.

Ullyott J.S., Nash D.J., Whiteman C.A., Mortimore R.N., 2004. Distribution, petrology and mode of development of silcretes (Sarsens and Puddingstones) on the Eastern South Downs, UK. Earth Surface Processes and Landforms, 29: 1509-1539.

Vierek A., 1997. Geneza górnojurajskich osadów z odsłonięcia w Bydlinie. Przegląd Geologiczny, 45(4): 428-430.

Vierek A., Lewandowski J., Malik K., Salomon T., 2011. Karpaty i ich przedpole. Przewodnik do ćwiczeń terenowych z sedymentologii. Wydawnictwo Uniwersytetu Śląskiego, Katowice: 28-31.

Żero E., 1956. Szczegółowa mapa geologiczna Polski, 1:50 000, arkusz Chrzanów. Państwowy Instytut Geologiczny, Warszawa.

\section{Websites}

http://geoportal.pgi.gov.pl/portal/page/portal/geostanowiska http://gminyturystyczne.pl/pokaz/trzebinia http://www.trzebinia.pl/_files_/zielone_perly.pdf 